\title{
Scrub typhus meningitis: a clue so near
}

\author{
Siddharth Neelakandan, Stalin Viswanathan ำ , Jayachandran Selvaraj, \\ Vivekanandan Pillai
}

General Medicine, Jawaharlal Institute of Postgraduate Medical Education, Puducherry, Tamil Nadu, India

\section{Correspondence to}

Dr Stalin Viswanathan; stalinviswanathan@ymail.com

Accepted 6 April 2021

\section{DESCRIPTION}

A 45-year-old woman from Cuddalore district, South India, came to the emergency medicine department with a history of fever, headache, myalgia and vomiting of 17 days duration, dizziness, generalised limb weakness of 3 days duration that had her confined to bed. She had been treated in another hospital with intravenous ceftriaxone for 3 days following which her fever intensity had reduced. She was dehydrated at admission, had oral herpes labialis, low-grade fever $(99.8 \mathrm{~F})$, mild weakness (4/5 lower limbs and left upper limb, 5/5 right upper limb), depressed deep tendon reflexes, bilateral flexor plantar reflex, neck stiffness and positive Kernig's sign. The rest of the systemic examination was normal. We considered a meningitic illness with lower motor neuron quadriparesis, probably a radiculoneuropathy, which was improving. Investigations revealed haemoglobin $98 \mathrm{~g} / \mathrm{L}(12-14)$, total leucocyte count $12.6 \times 10^{9} / \mathrm{L}\left(4-10 \times 10^{9}\right)$, platelets $350 \times 10^{9} / \mathrm{L}\left(150-450 \times 10^{9}\right)$, blood sugar $137 \mathrm{mg} / \mathrm{dL}$ (141-200), creatinine $0.9 \mathrm{mg} / \mathrm{dL}(0.8-1.2)$, sodium $135 \mathrm{mEq} / \mathrm{L}(135-145)$, potassium $3.2 \mathrm{mEq} / \mathrm{L}$ (3.55.0), chloride $96 \mathrm{mEq} / \mathrm{L}$ (95-110), total bilirubin $1.2 \mathrm{mg} / \mathrm{dL}$, aspartate transaminase $-78 \mathrm{U} / \mathrm{L}(<40)$, alanine transaminase $54 \mathrm{U} / \mathrm{L}(<35)$ and alkaline phosphatase 112 U/L $(<125)$. Cerebrospinal fluid (day 2) showed 20 cells $(<5)$, with 12 neutrophils and 8 lymphocytes, sugar $68 \mathrm{mg} / \mathrm{dL}$, protein $81 \mathrm{mg} /$ $\mathrm{dL}(<40)$ and was negative for acid-fast bacilli, India ink staining and GeneXpert for tuberculosis. A partially treated meningitis or a tuberculous meningitis was considered; ceftriaxone was continued and antitubercular therapy was planned. A CT (day 1)

\section{Patient's perspective}

(Daughter) The doctors gave a diagnosis of partially treated brain fever, but my mother did not recover completely with intravenous injections. Though I noticed the scab on her back while changing her clothes during the early part of her illness, it never crossed my mind that it was the culprit all along. Thereafter the treatment was so easy, and my mother made rapid recovery.

\section{Learning points}

- In patients from endemic areas, acute febrile illness and meningeal signs should merit a thorough search for eschars.

- Long duty hours make physicians prone to errors of omission.

of the brain and MRI (day 6) with contrast were normal. There was no leptomeningeal enhancement. Though fever subsided, her nausea, vomiting, anorexia and headache persisted. Two days later, her febrile panel revealed Lepto IgM positivity, negative malarial antigen and negative PCR (in cerebrospinal fluid) for scrub typhus and herpes encephalitis (1 and 2). Only then the resident remembered that an eschar had been noticed at the site of lumbar puncture during the procedure (figure $1 \mathrm{~A}, \mathrm{~B}$ ). The resident's duty had been hectic, and documentation of the eschar was forgotten. Oral doxycycline $100 \mathrm{mg}$
Check for updates

(c) BMJ Publishing Group Limited 2021. No commercial re-use. See rights and permissions. Published by BMJ.

To cite: Neelakandan $S$, Viswanathan S, Selvaraj J, et al. BMJ Case Rep

2021;14:e242377.

doi:10.1136/bcr-2021-

242377

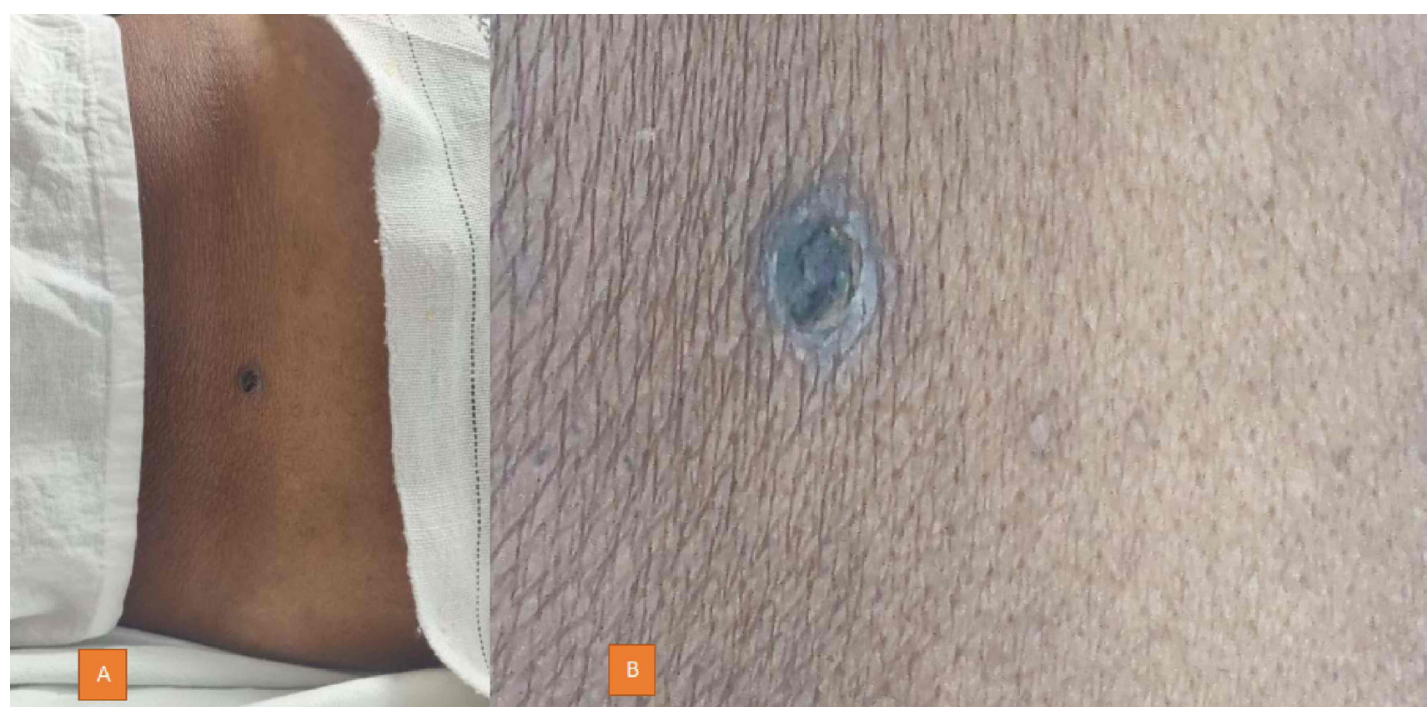

Figure 1 (A) Eschar noticed at the site of lumbar puncture before the procedure. (B) Close-up view of the eschar. 
two times per day (due to unavailability of intravenous preparation) was then initiated, 3 days after which all her symptoms except nausea subsided. Despite her upper gastrointestinal symptoms, she tolerated doxycycline without vomiting the doses that were administered. Upper gastrointestinal endoscopy performed for her nausea was normal. She was managed with intravenous pantoprazole and metoclopramide. At discharge she was advised to complete a 14-day course of doxycycline along with omeprazole. The presence of eschar at the bite-site is a specific marker for the clinical diagnosis of scrub typhus (98.9\%). ${ }^{1}$ Also, the scrub PCR assay's sensitivity was $86.5 \%$ according to one study. ${ }^{2}$ There are many case reports of serological dual positivity for scrub and leptospirosis, but most of them are due to a single infection with cross-reacting antibodies or a recent past infection of the other. ${ }^{2}$ Both these infections differ in their management, although mild leptospirosis and scrub typhus can be managed with doxycycline alone. In our case, the test was suggestive of leptospirosis, but the eschar clinched the diagnosis, although late. She denied our request to return for a repeat scrub IgM since she had gained new employment after her discharge from hospital and was unable to forgo her daily wages.

Contributors $\mathrm{SN}$-drafted manuscript and literature review. SV—images and conception. JS-literature review. VP-editing and approval.

Funding The authors have not declared a specific grant for this research from any funding agency in the public, commercial or not-for-profit sectors.

Competing interests None declared.

Patient consent for publication Obtained.

Provenance and peer review Not commissioned; externally peer reviewed.

ORCID iD

Stalin Viswanathan http://orcid.org/0000-0001-5861-5161

\section{REFERENCES}

1 Kala D, Gupta S, Nagraik R, et al. Diagnosis of scrub typhus: recent advancements and challenges. 3 Biotech 2020;10:1-21.

2 Gupta N, Chaudhry R, Mirdha B. Scrub typhus and leptospirosis: the fallacy of diagnosing with IgM enzyme linked immunosorbant assay. J Microb Biochem Technol 2016;08:071-5.

Copyright 2021 BMJ Publishing Group. All rights reserved. For permission to reuse any of this content visit https://www.bmj.com/company/products-services/rights-and-licensing/permissions/

BMJ Case Report Fellows may re-use this article for personal use and teaching without any further permission

Become a Fellow of BMJ Case Reports today and you can:

- Submit as many cases as you like

- Enjoy fast sympathetic peer review and rapid publication of accepted articles

- Access all the published articles

Re-use any of the published material for personal use and teaching without further permission

Customer Service

If you have any further queries about your subscription, please contact our customer services team on +44 (0) 2071111105 or via email at support@bmj.com.

Visit casereports.bmj.com for more articles like this and to become a Fellow 